\title{
Pengembangan Sistem Informasi Pengukur Kesiapan Akreditasi Program Studi 9 Kriteria
}

\author{
Aswad $^{1}$, Heliawati Hamrul${ }^{2}$, Nuralamsah Zulkarnaim ${ }^{3}$ \\ ${ }_{1,2,3}$ Informatika, Teknik, Universitas Sulawesi Barat \\ 1'aswadcoy@gmail.com, ${ }^{2}$ heliawatyhamrul@unsulbar.ac.id, ${ }^{3}$ nuralamsyah@unsulbar.ac.id
}

\begin{abstract}
The accreditation system is a form of assessment (evaluation) of the quality and feasibility of higher education institutions or study programs carried out by independent organizations or bodies outside universities. The assessment is used as a quality benchmark for all study programs and higher education institutions, both from public and private universities that organize professional and academic programs. The better the value of accreditation will have an impact on the views of outsiders regarding the quality of the study program and higher education institution. However, the collection of data and information as well as filling out forms in the informatics study program still have many obstacles, such as the large number of data used as assessment criteria that requires a lot of time and effort. And also continuously accreditation that keeps repeating every few years is one of the problems faced in storing the accreditation data. Therefore, we need an information system that is able to integrate the entire contents of the supporting data so that during the evaluation process information is obtained about what parts are lacking and have met the standards. From the research that has been done, the results show that the system can run as expected so that researchers expect the use of this accreditation system to provide an overview of the accreditation value of study programs, and study program managers can take action to prepare and improve accreditation status so that they can get the highest score.
\end{abstract}

Keywords: Accreditation, forms, system

\begin{abstract}
Abstrak
Sistem akreditasi merupakan salah satu bentuk penilaian (evaluasi) mutu dan kelayakan institusi perguruan tinggi atau program studi yang dilakukan oleh organisasi atau badan mandiri di luar perguruan tinggi. Penilaian tersebut digunakan sebagai tolak ukur mutu bagi semua program studi dan intitusi pendidikan tinggi baik dari perguruan tinggi negeri maupun swasta yang menyelenggarakan program professional maupun akademik. Semakin baik nilai akreditasi akan berdampak pada pandangan pihak luar mengenai kualitas program studi dan institusi pendidikan tinggi tersebut. Namun pengumpulan data dan informasi serta pengisian borang pada program studi informatika masih memiliki banyak kendala seperti banyaknya data-data yang dijadikan sebagai kriteria penilaian membutuhkan banyak waktu dan usaha. Dan juga secara terus menerus akreditasi yang terus berulang setiap beberapa tahun merupakan salah satu masalah yang dihadapi dalam penyimpanan data-data akreditasi tersebut. Oleh karena itu, diperlukan sebuah sistem informasi yang mampu mengintegrasikan keseluruhan isi data pendukung sehingga saat proses evaluasi didapatkan informasi mengenai bagian-bagian apa saja yang kurang dan sudah memenuhi standar. Dari penelitian yang telah dilakukan diperoleh hasil bahwa sistem dapat berjalan sesuai dengan yang diharapkan sehingga peneliti mengharapkan penggunaan sistem akreditasi ini dapat memberikan gambaran tentang nilai akreditasi program studi, dan pengelola program studi dapat melakukan tindakan untuk mempersiapkan dan meningkatkan status akreditasi sehingga dapat memperoleh nilai tertinggi.
\end{abstract}

Kata kunci: Akreditasi, borang, sistem 